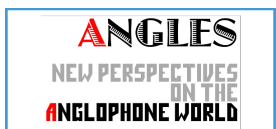

\section{Angles}

New Perspectives on the Anglophone World

$4 \mid 2017$

Unstable States, Mutable Conditions

\title{
Intertwined Languages and Broken Flows: Reading Ontological Polyphonies in Lower Murray Country (South Australia)
}

\section{Camille Roulière}

\author{
(2) OpenEdition \\ 1 Journals \\ Electronic version \\ URL: https://journals.openedition.org/angles/1404 \\ DOI: 10.4000/angles. 1404 \\ ISSN: 2274-2042 \\ Publisher \\ Société des Anglicistes de l'Enseignement Supérieur
}

\section{Electronic reference}

Camille Roulière, "Intertwined Languages and Broken Flows: Reading Ontological Polyphonies in Lower Murray Country (South Australia)", Angles [Online], 4 | 2017, Online since 01 April 2017, connection on 07 June 2022. URL: http://journals.openedition.org/angles/1404 ; DOI: https://doi.org/ 10.4000 /angles. 1404

This text was automatically generated on 7 June 2022

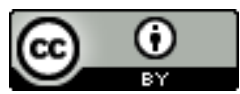

Angles est mise à disposition selon les termes de la Licence Creative Commons Attribution 4.0 International. 


\title{
Intertwined Languages and Broken Flows: Reading Ontological Polyphonies in Lower Murray Country (South Australia)
}

\author{
Camille Roulière
}

1 As a brief preamble, two aspects of this work require explanations.

2 First, the presentation of this essay is unconventional. It is primarily visual and to be understood, literally and figuratively, as a tableau in the dual French meaning of the term, i.e. as both table and picture. The graphic aspect of this non-linear vis-à-vis format was deemed the most constructive manner to achieve the article's aim of preserving the opacity of Ngarrindjeri discourses, while shedding new light on the interdependency between the "hyphenated" histories (Johnson 2014: 318), both current and historical, of governmental and Ngarrindjeri ontologies and practices in relation to waters.

3 This format allows for the author's interpretative imaginary to be made explicit: this is its picture side. Ngarrindjeri quotations, extracted from material released and/or compiled by the Ngarrindjeri to support their projects, are separated from the body of the analytical text and presented as a picture framed between two dotted lines. This clear demarcation and relational apposition between the authorial voice, italicised theoretical definitions used as epigraphs and Ngarrindjeri discourses appearing as quotes generates a productive tension, the aim of which is to deconstruct the representational practice of the "Other".

4 This format also allows for autonomous and spontaneous connections between the cells, visually placed in dialogue: this corresponds to its table format. These reactional interactions are not designed solely as oppositions, but as infinite potential "juxtapositions" (Binney 1995) of multiple and multiplying realities. As each reader becomes involved and (re)(dis)connects the cells, the ontological divide between governmental and Ngarrindjeri discourses is to be interpreted as a deforming space 
filling with burgeoning polyphonies, rather than as the manifestation of an unbridgeable and absolute schismatic void. I also decided to insert a set of photographs which I took in 2015. These seemingly innocuous illustrations contribute to further disrupting the expected linearity of the reading experience by requiring yet another type of engagement from the readers. As they transition between text and photograph and unconsciously translate one into the other, their responsibility becomes involved: they are themselves bringing a vision of Lower Murray Country into being.

5 Second, I must stress that the insights I offer come from a specific perspective: I am white, French-Australian, middle-class, and tertiary-educated. My "gaze" (Pratt 1992) belongs to the dominant majority which still continues to define and shape Aboriginality from the outside, and writing this article indubitably raises a number of ethical issues. The representational challenges posed by such an endeavour are sorely rooted in centuries of colonial practices, ranging from a denigrating essentialism to a mode of celebratory appropriation. My aim here, in an attempt to avoid reproducing these oppressive patterns, is to disrupt representational boundaries: left to speak for themselves, Ngarrindjeri quotations retain their opacity (i.e. the expression of what cannot be articulated) as I abandon, to a certain degree, a performative discursive authority by way of the renunciation of a purely demonstrative and/or argumentative logic.

\section{Understanding the Waters of Lower Murray Country}

Birds in Lower Murray Country

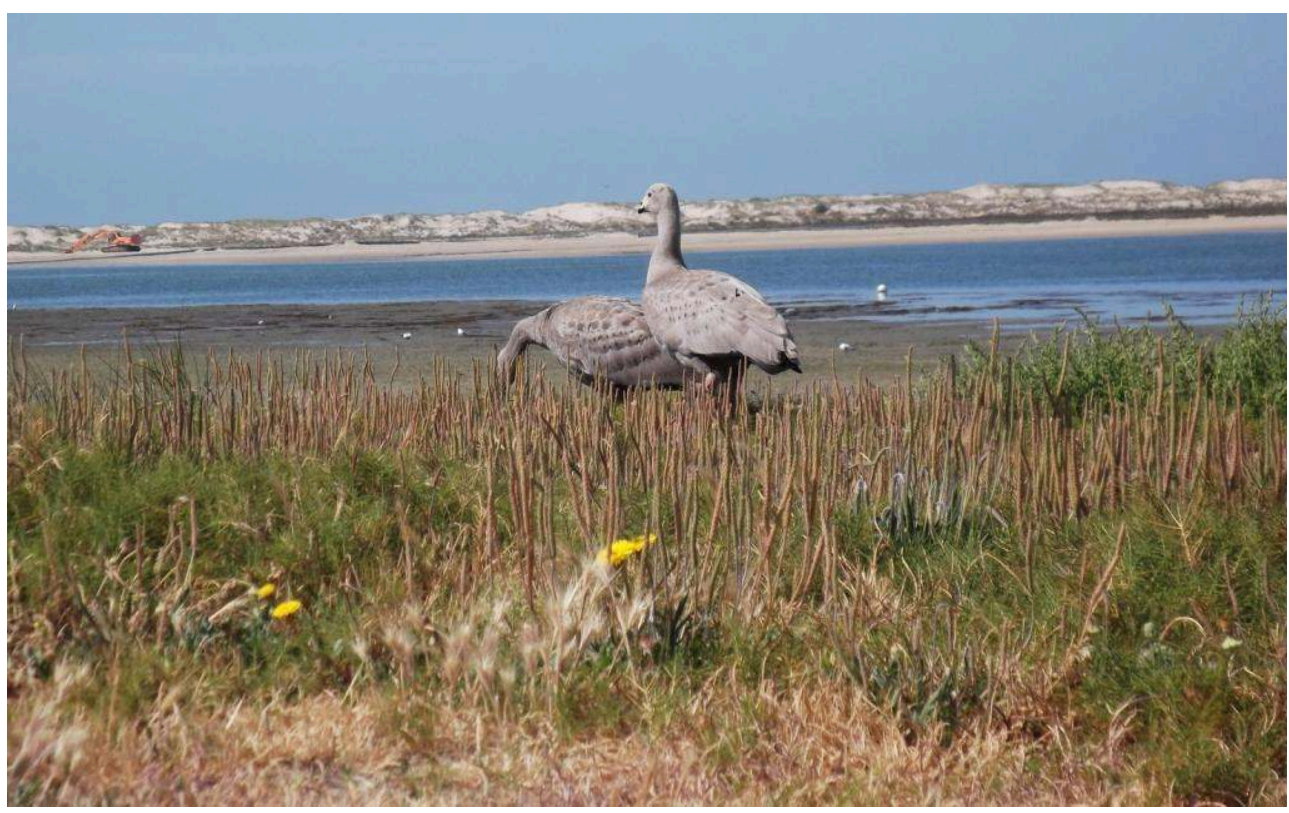

All pictures by the author. 
Western Discourses: the government's voice

The quest for water, deemed to represent a source of mobility, development and commerce, whose hypothetical presence and abundance were tantamount to a good omen, figured at the centre of the European colonial imaginary in Australia. Australian waters nonetheless proved a source of disappointment and frustration: difficult to locate, lacking permanence, behaving unexpectedly and disappearing prematurely (Carter 1987: 54-60). When European explorers stumbled upon Murray River Country in the 1820 s, it nonetheless represented an acceptable materialisation of their long-held dream. The physicality of the waters empirically substantiated the promise of riches and allowed for the projection of the squatters' expectations, as a result of which this fertile region was promptly settled. An agricultural industry burgeoned. In the settler's imagination, this fastgrowing industry quickly emerged as a business of national importance upon which potential development success rested, and rests still (Robin 2007: 207-209; Alexandra and Riddington 2007: 326). Water management, centred on

angricultural 4 needs, became indispensable to support this ever-expanding pastoral vision (Regulation Impact Statement 2012: vii,

Aboriginal Discourses: Ngarrindjeri voices

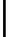


Western science
The Basin Plan (the
MDBA's regulating project
governing uses for Murray
River Country's waters), is
informed, through and
through, by the "best
available" Western

scientific knowledge (RIS

19, 85; Report 62; MDBA

Website's "Publications"

tab). As such, Western

science is the systematic

rationale behind water

understanding and

management, as promoted

in and through

governmental managerial practices in Murray River Country and, consequently, in Lower Murray Country. This can be no surprise: in Australia, as in other settler colonial countries (Dunlap 1999), there is a century-long history of governmental promotion and use of science as the nation's building tool to move forward and into the future (Robin 2007).

Such scientific foundations mean two things in terms of the articulated water understanding: first, it is rooted in Western ontology, and is thus globalising; second, it is capitalistic and builds an antinomic conception between ecological and economic waters.

Government promoted centrality and authority granted to Western science secures the understanding of Australian waters within a wider Western ontological frame. As part Angles, 4hihs 2017 transposition, scientific technicality is anchored as a universal truth, to the detriment of a location-bound 
Bulls on Kumarangk (Hindmarsh) Island

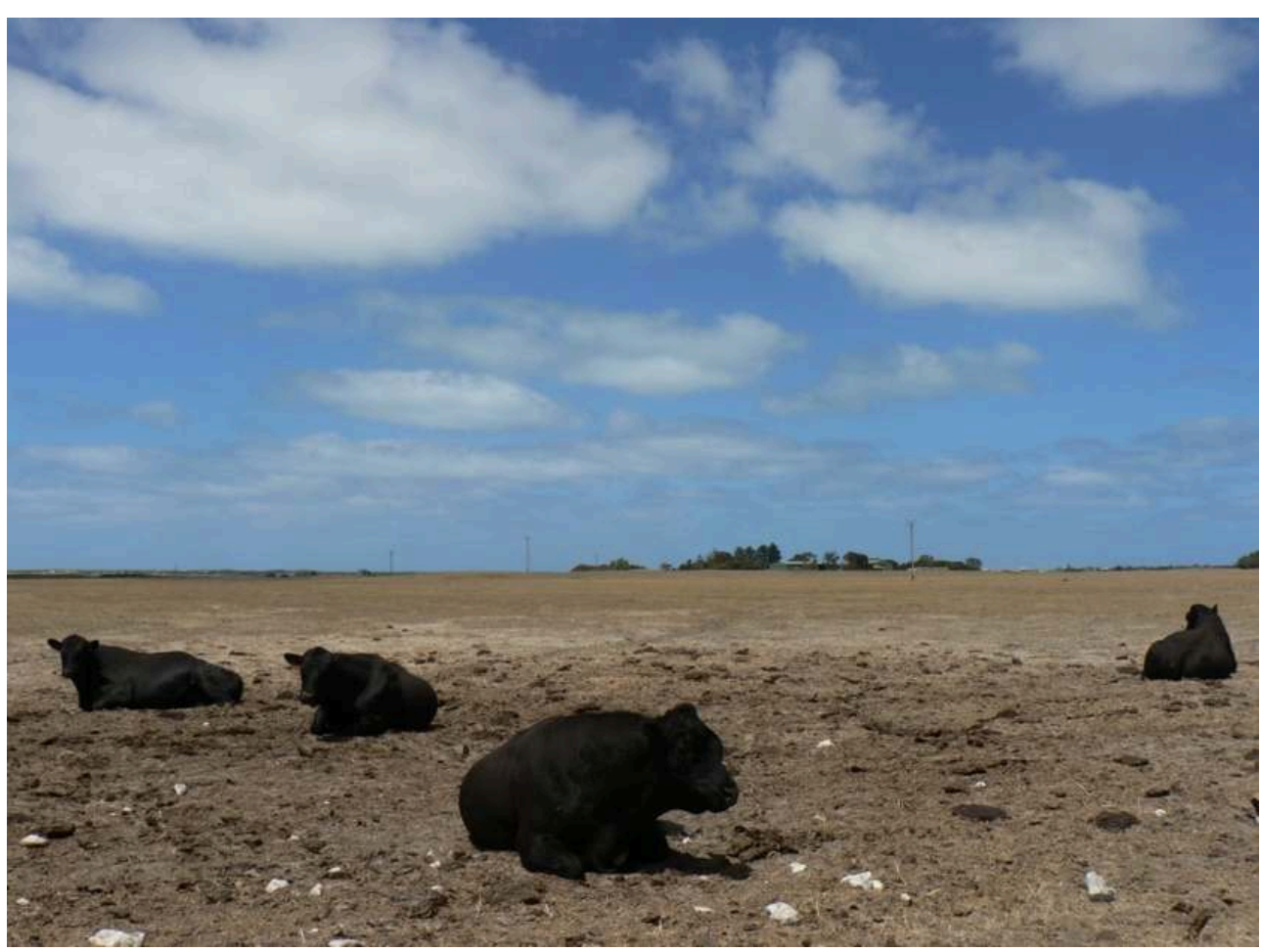




\begin{tabular}{|c|c|}
\hline $\begin{array}{l}\text { Measuring also fragments } \\
\text { and compartmentalises } \\
\text { Murray River Country. It } \\
\text { contributes to "fixing" the } \\
\text { waters by transforming } \\
\text { flows into predictable and } \\
\text { manageable data, through } \\
\text { increased regulation. This } \\
\text { transformation, combined } \\
\text { with mathematical } \\
\text { metonymy, turns waters into } \\
\text { completely disconnected and } \\
\text { disembodied resources: a } \\
\text { non-existent ecological }\end{array}$ & 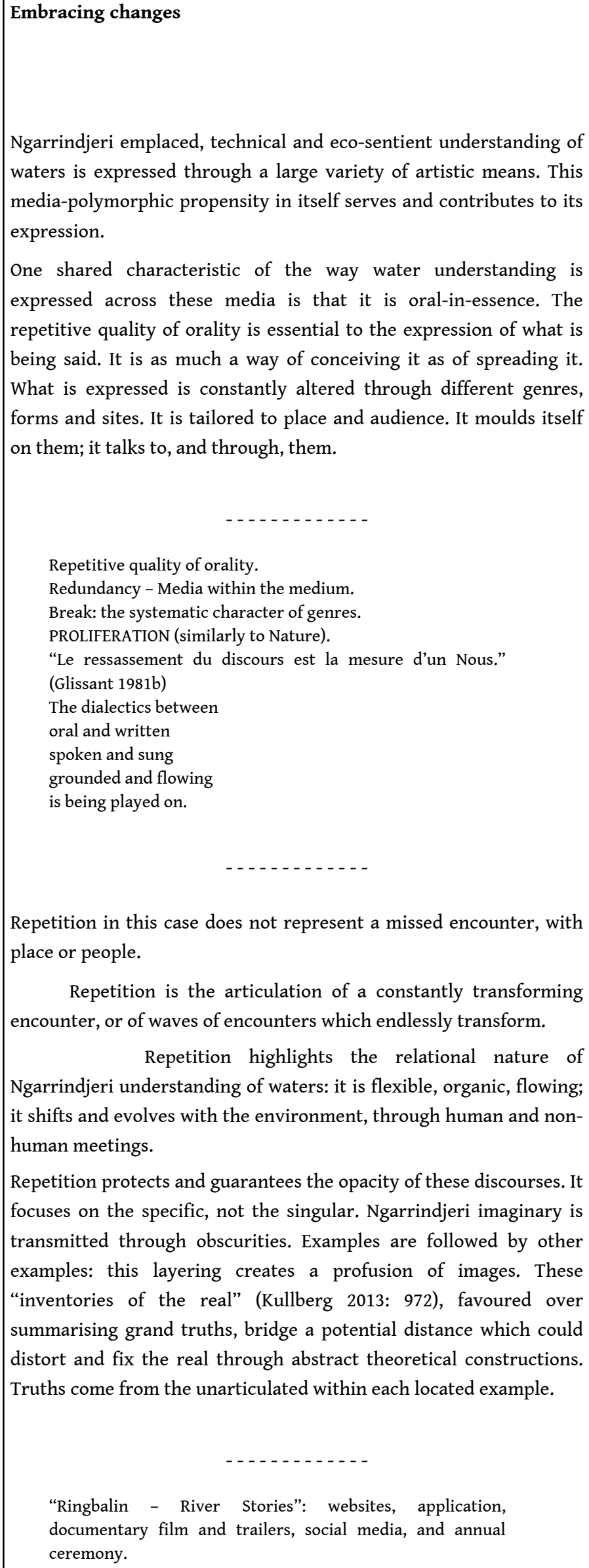 \\
\hline $\begin{array}{l}\text { Angles, } 4: 2017 \text { aters tend to } \\
\text { spread out and form "dis- } \\
\text { tributaries" rather than } \\
\text { permanently }\end{array}$ & Repetition is humid. \\
\hline
\end{tabular}


Dredgers working at the Murray Mouth

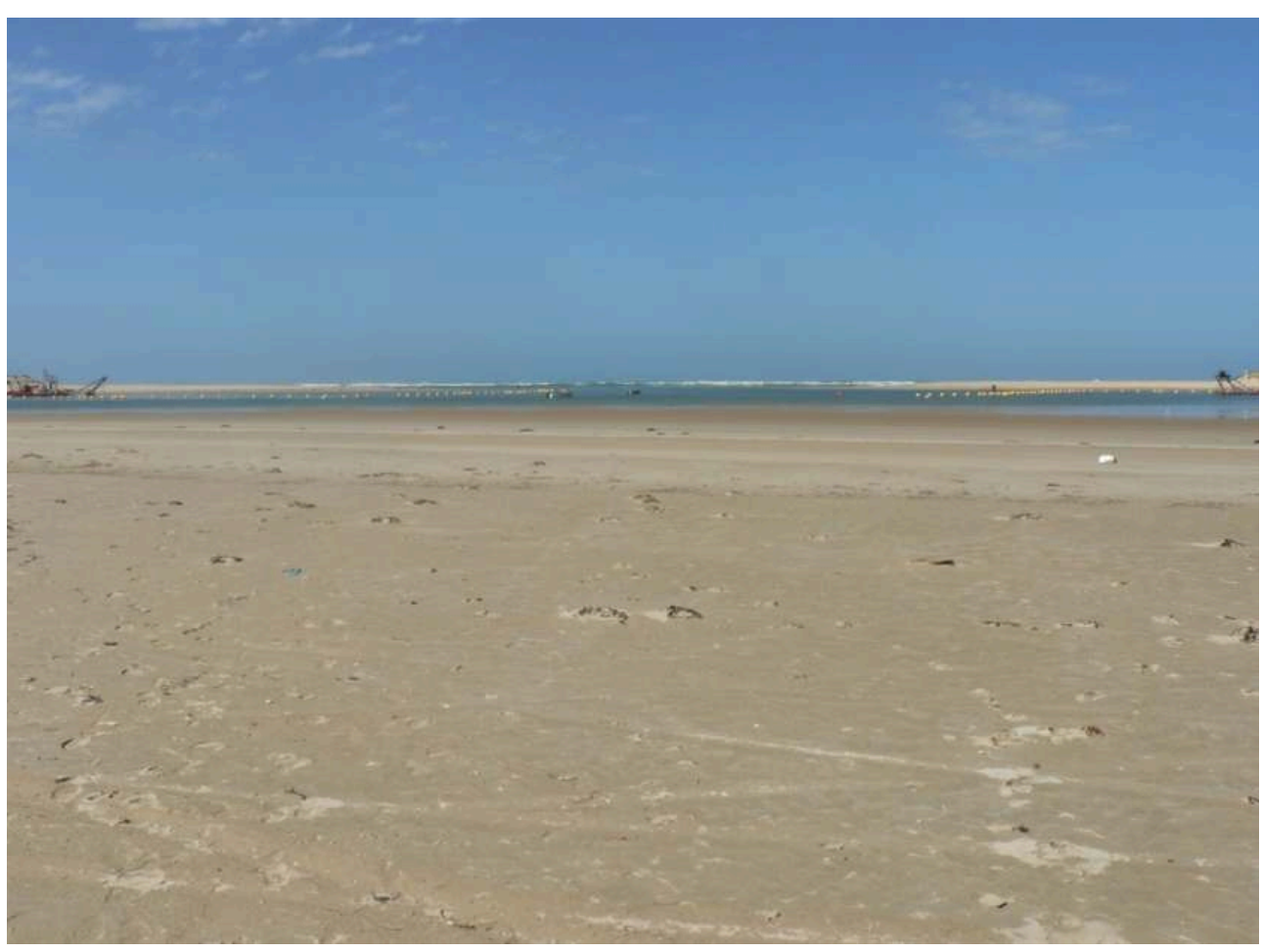

\section{Lower Murray Country}

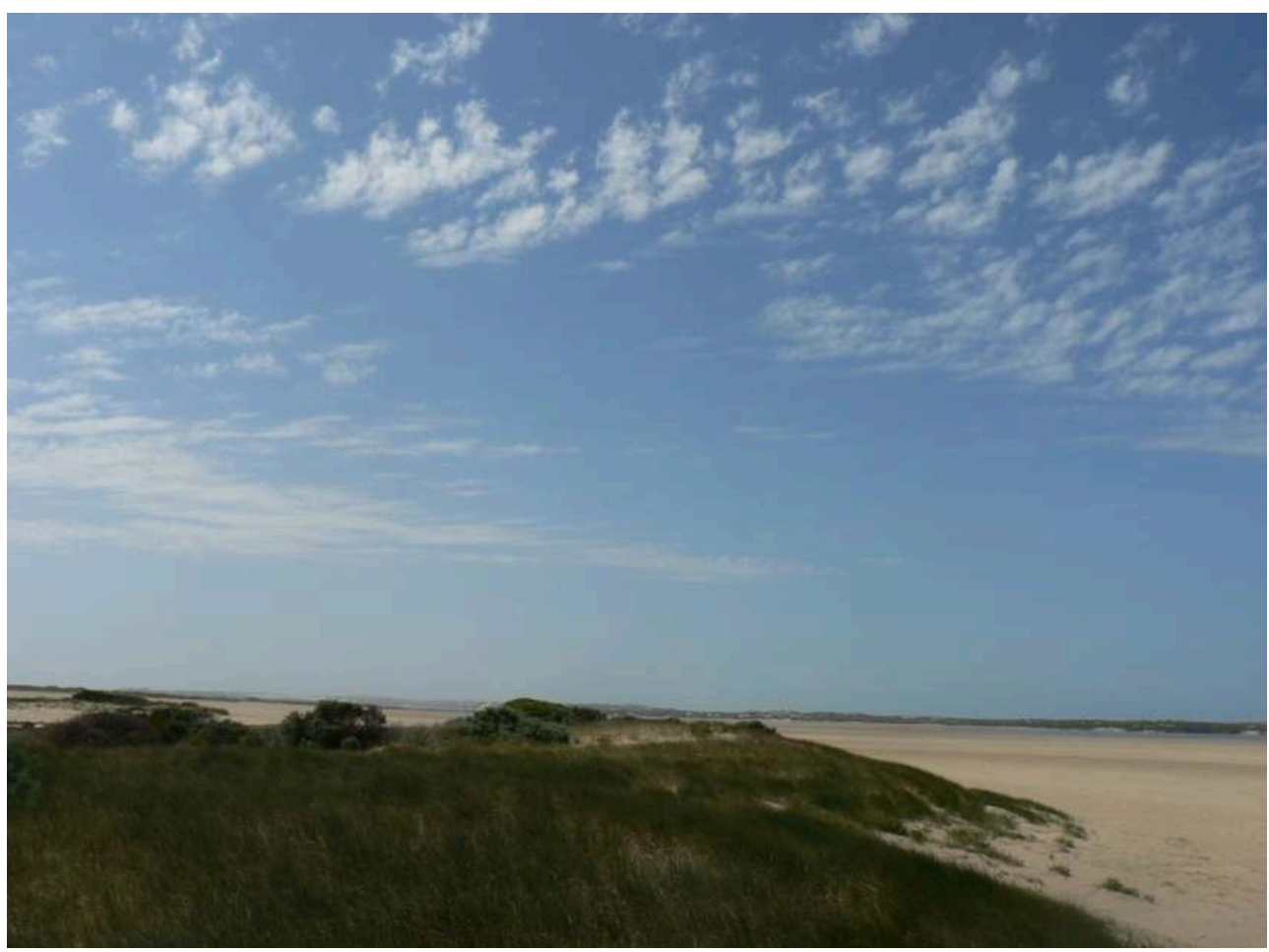




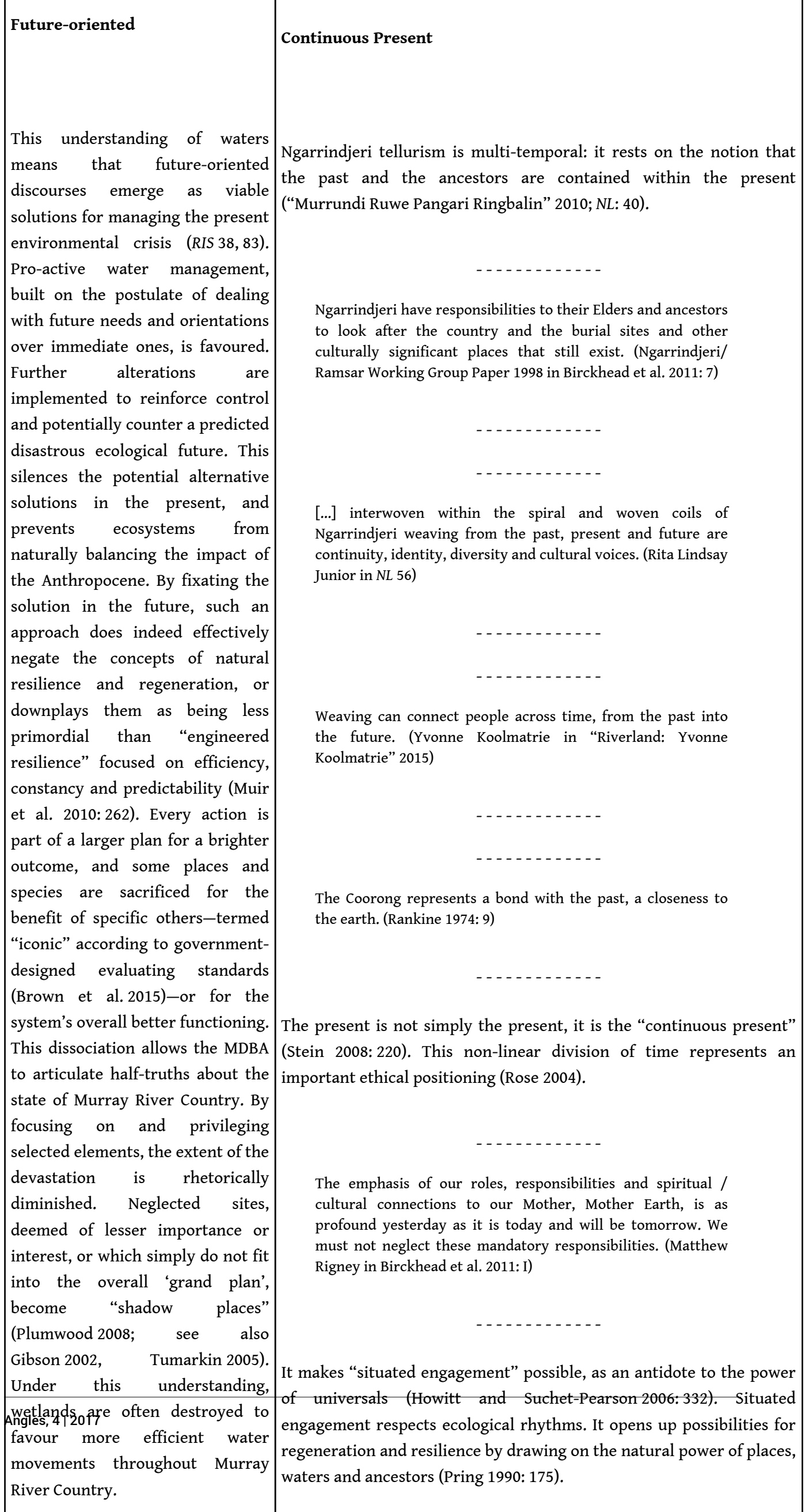




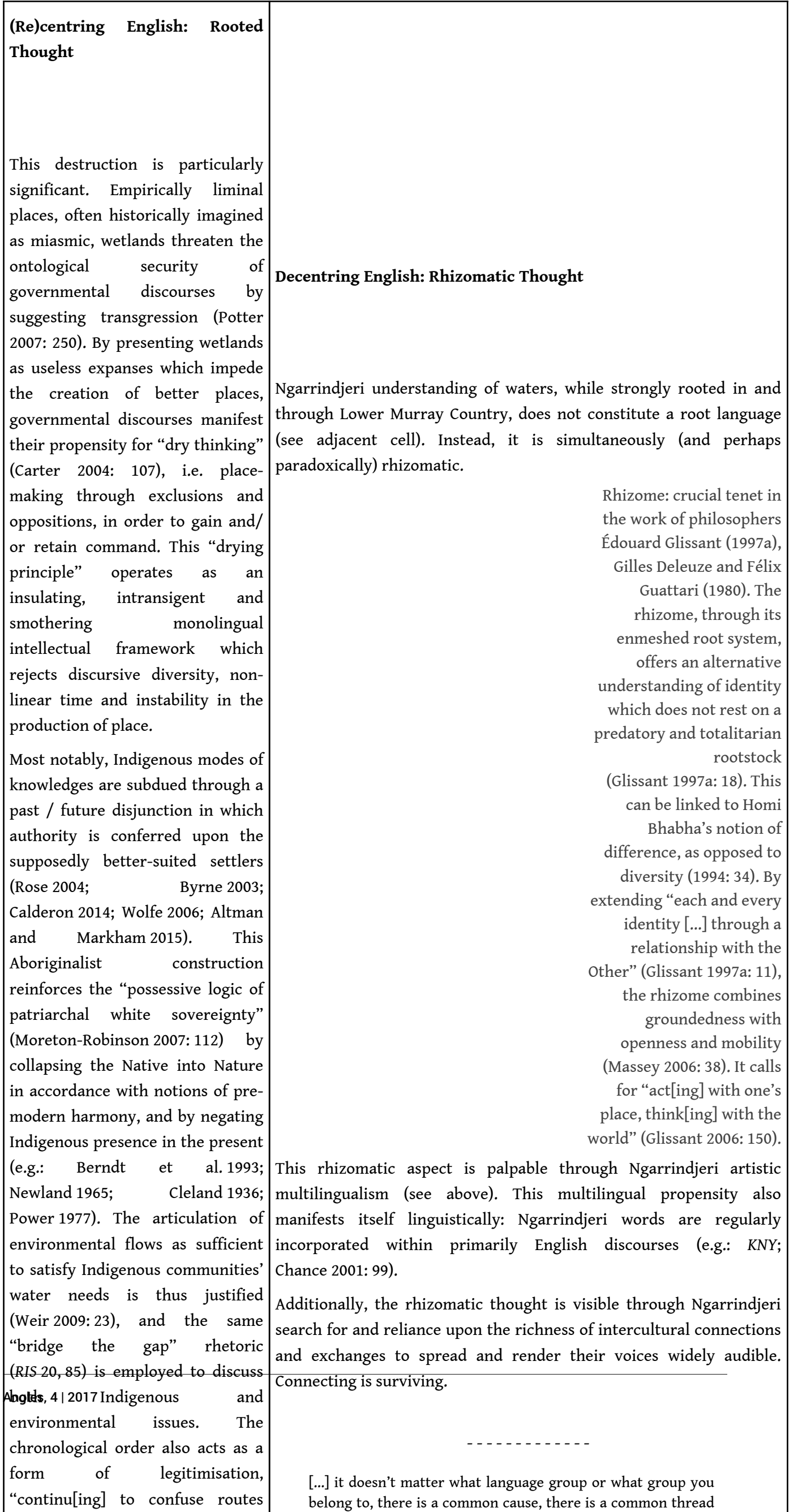


Lower Murray Country

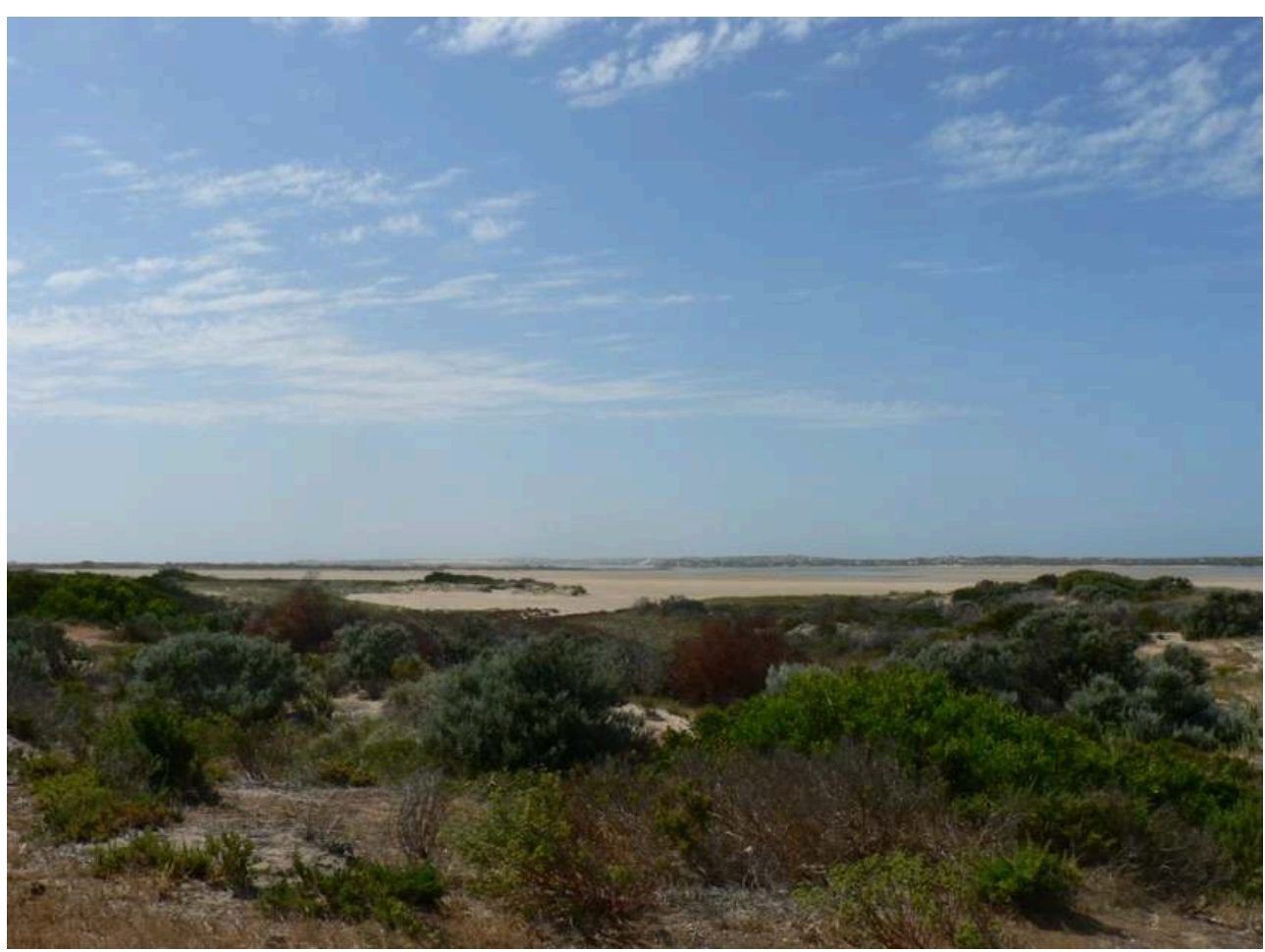


Imperialist Discourses

Imported from evergreen Great Britain and imposed on the pulsative water ecologies of the Australian continent, the articulated understanding of waters is a copy-pasted grand verbal delirium anchored in Western aesthetics. Ecologically unadapted and disconnected, these discourses encapsulate a declamatory language of abstraction through which oppression is recorded and sustained (Tjukonia 2003, Glissant 1981b). A capitalist, metonymic and drying narrative of progress is used to generate a "destructive breach between human and non-human worlds" (Potter 2007: 251-2). This justifies the (ontological) separation of humans from their distinct non-human environment, which is relegated to being a décor, a theatrical space and territory primarily designed for a performative self-demonstration of technological skills and engineering ingenuity, leading to the creation of a vast agricultural heartland open to exponential economic profits. Waters do not belong to place. Severed from their entangled and intertwined ecosystems and the complex web of relations they form, they have become the epicentre through which disembodied geographies can be created. Waters are reduced to the status of a non-existent ecological entity metonymically symbolised by numbers, a quantified and thus manageable resource, which can and should be controlled and exploited.

Governmental discourses are thus languages of colonialism: they sustain and seemingly justify the implementation of mutated colonial practices, exhibiting a clear genealogy to old forms of colonialism over humans and non-humans alike, in order to satisfy "a vision of drought-proof Australia" (Potter 2007: 247). Part of a "practical reconciliation" agenda, they present "the final colonial act (normalising the outcome of Angles, $4 \mid 2017, "$ as justice (Hattam et al. 2007: 110-117).

Over two hundred years after their first implementation on Australian landscapes,
Baroque Speech

Ngarrindjeri ethnopoetics can be interpreted as Baroque speech, as defined by Édouard Glissant, i.e. a "worlded" yet highly localised speech.

The Baroque: historically, "a reaction against the rationalist pretence of penetrating the mysteries of the known with one uniform and conclusive move" (1997a: 77; also 1987: 18). The Baroque represents a crisis of meaning. It eschews transparency and stands against monological uniformity achieved through the dissection of the world and its expression into conceptually fixed, separated and bounded forms and datasets (1997a: 79; also Plumwood 2002: 49; Latour 1991). It is extension, proliferation, redundancy and repetition (1995: 70; 1990: 57). It is unstable and plural, constantly and endlessly reformulated through extreme inclusion and expansion (1997a; Carpentier 1995: 93). The Baroque is thus born and thrives from "precipitate" cultural contacts and exchanges (1997a: 163). Social relationships and crossfertilisations are crucial to its formation and development (1987: 19). Such a Baroque is a world philosophy which goes "beyond an aesthetic mood to represent the contemporary global cultural dominant of creolisation and Relation" (Oakley 2011: 276). Glissant writes: "In sum, there is a 'naturalisation' of the baroque, no longer only as art and style, but also as a manner of living the unity-diversity of the world [...]." (1997a: 79; also 1987: 19) Despite this worlded connectivity, the Baroque remains strongly dependent upon locality. It is always rooted in and shaped by a terroir: "it is literally identical to nature, directly expressive of nature" (Hallward 2001:123). Such an understanding of the Baroque has been termed a "New World Baroque", a "rebellious Baroque" which can be assimilated to "a decolonising strategy to deform-creolise-the metropolitan standard" (Zamora and Kaup 2010: 622). It plays with representation and transculturation, performing as a counter-conquest form of expression which deconstructs and decentres (rearranging and re-presenting) the Western cultural "storehouse" (Tuhiwai-Smith 1999).

This conception of the Baroque is particularly tangible in language and Glissant develops the related notion of Baroque speech, propelled by similar relational yet rooted propensities (1990). Baroque speech offers an essential "disturbance against certainty" and represents the "intersubjective extension of a favourable site for the multiplication of a multitude of diverse and new realities" (1997a: 79, 203). It is "world-music": polymorphic and multifaceted, "inspired by all 


\section{The Lowelr Lakes}

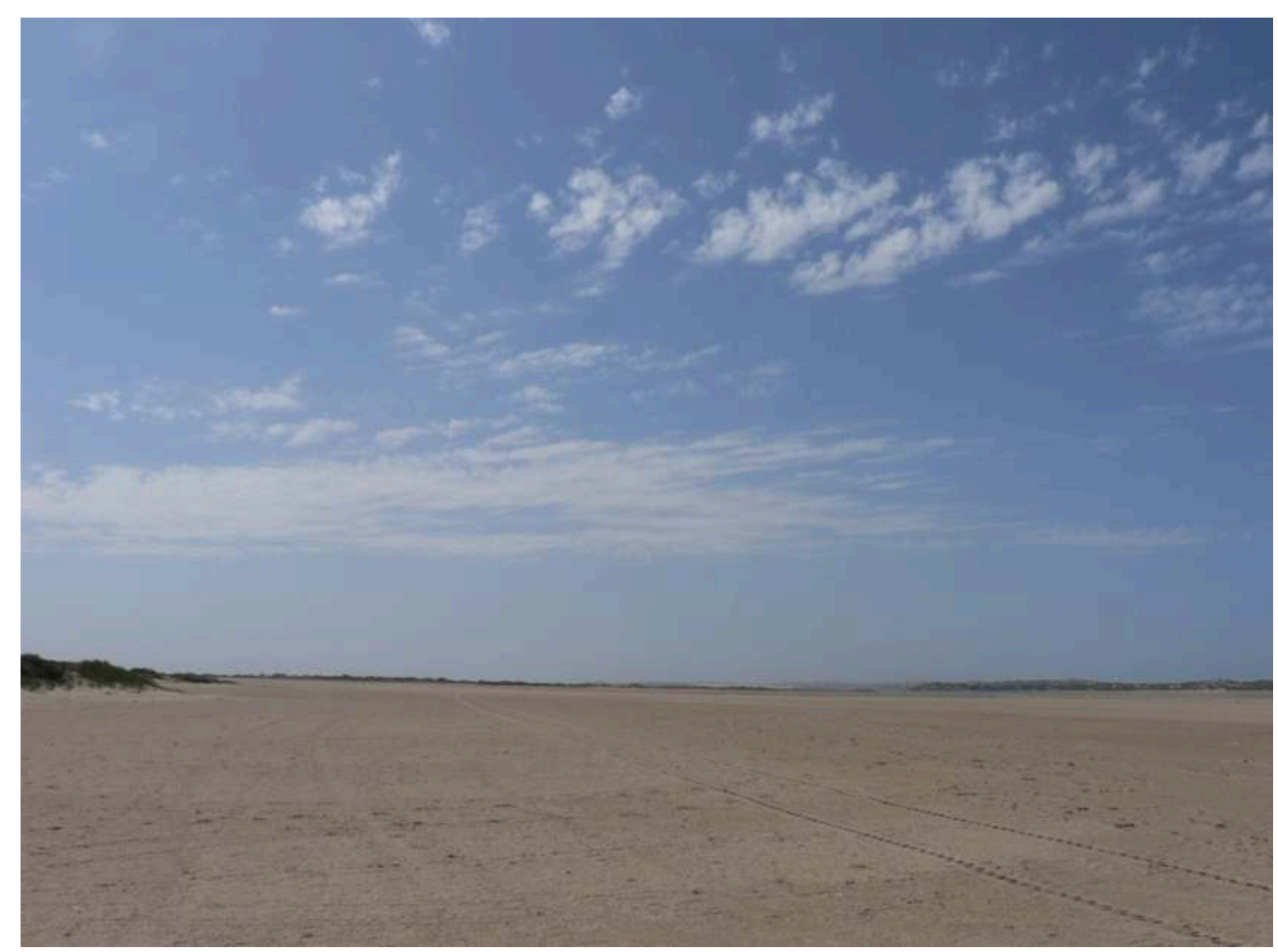

\section{BIBLIOGRAPHY}

\section{Governmental Water Management Body}

Annual Report 2014-1015: Working Together to Improve the Health of the Murray-Darling Basin. MDBA Reports. MDBA, 17 Dec. 2015. Web. [outdated link: http://www.mdba.gov.au/publications/mdbareports/murray-darling-basin-authority-annual-report-2014-15] updated link:_https:// web.archive.org/web/20160702093105/https://www.mdba.gov.au/publications/mdba-reports/ basin-environmental-watering-outlook-2016-17

Basin environmental watering outlook for 2016-17. MDBA Reports. MDBA, 11 April 2016. http:// www.mdba.gov.au/publications/mdba-reports/basin-environmental-watering-outlook-2016-17 Explanatory Statement: Basin Plan 2012. Federal Register of Legislation, Commonwealth of Australia. Web. 19 Dec. 2015. https://www.legislation.gov.au/Details/F2012L02240/

Explanatory\%20Statement/Text

Live Data. Commonwealth of Australia (Murray-Darling Basin Authority). Web. 3 Feb 2016. http:// livedata.mdba.gov.au/ 
Murray-Darling Basin Authority. Commonwealth of Australia (Murray-Darling Basin Authority). http://www.mdba.gov.au/

Regulation Impact Statement. Commonwealth of Australia (Murray-Darling Basin Authority). MDBA Reports. MDBA, Nov. 30, 2012. http://www.mdba.gov.au/publications/mdba-reports/regulationimpact-statement

The Basin Plan: A Concept Statement. MDBA Brochures and Factsheets. MDBA, 1 Jan. 2009. http:// www.mdba.gov.au/publications/brochure/basin-plan-concept-statement

'The Living Murray Story: One of Australia's largest river restoration projects.' MDBA Reports. MDBA, 25 Oct. 2011. http://www.mdba.gov.au/publications/mdba-reports/living-murray-story

\section{Ngarrindjeri Cultural Weaver Yvonne Koolmatrie}

"Riverland: Yvonne Koolmatrie." Tarnanthi: Festival of Contemporary Aboriginal and Torres Strait Islander Art. Exhibition, Galleries 9, 10 and 11. Curated by Nici Cumpston, Jonathan Jones and Hetti Perkins, with Yvonne Koolmatrie and Genevieve O'Callaghan. Art Gallery of South Australia. 12 Sept. 2015 to 10 Jan. 2016.

Riverland: Yvonne Koolmatrie. Exhibition Catalogue. Adelaide: Art Gallery of South Australia, 2015.

"Riverland: Yvonne Koolmatrie. » Interpretive Guide. Adelaide: Art Gallery of South Australia, 2015. [outdated link: https://www.artgallery.sa.gov.au/agsa/home/Learning/docs/ TARNANTHI_InterpretiveGuides/TARNANTHI_Interpretive_Guide_YVONNE_KOOLMATRIE.pdf] updated link: https://web.archive.org/web/20160621083242/https://www.artgallery.sa.gov.au/ agsa/home/Learning/docs/TARNANTHI_InterpretiveGuides/ TARNANTHI_Interpretive_Guide_YVONNE_KOOLMATRIE.pdf

\section{Ringalin}

"Murrundi Ruwe Pangari Ringbalin (River Country Spirit Ceremony)." MDBA Media. YouTube, 24 Nov. 2010. https://www.youtube.com/watch?v=GqrRfyVNqIo

Ringbalin - Breaking the Drought. Dir. Ben Pederick. Perf. Major Sumner, Cheryl Buchannan, Kooma/Gwamu Ngyiaampa and Ngarrindjeri: tribal dancers and performers, Ellen Trevorrow, Paul Gordon, Herb Wharton, Beryl Carmichael, Doreen Micthell, Barney Lindsay. Goodmorningbeautiful films in association with JDR Screen, 2013.

"Ringbalin - Breaking the Drought." Online video clip. Adelaide Film Festival. YouTube, 1 Sept. 2013. https://www.youtube.com/watch?v=exldNa9G-c8

"Ringbalin: Dancing the River." Ananguku Arts. Ananguku Arts and Culture Aboriginal Corporation, 2014. [outdated link: https://web.archive.org/web/20160412220116/http:// www.anangukuarts.com.au/about/Projects/p4070.aspx] updated link: https:// www.anangukuarts.com.au/blog/2017/9/28/rkrvg88a6imp47sred6g0y7i257u7b

Ringbalin, River Stories. Application. The Project Factory AU. https://itunes.apple.com/au/app/ ringbalin-river-stories-ceremony/id750925984?mt=8

Ringbalin, River Stories. The Project Factory AU. Web. 6 Dec. 2015. http://www.ringbalinriverstories.com/ 


\section{The National Cultural Flows Research Project}

The National Cultural Flows Research Project. National Native Title Council as trustee for the National Cultural Flows Planning and Research Committee, 2012. Web. 4 Jan. 2016. http:// culturalflows.com.au/

\section{Works Cited}

Alexandra, Jason and Curtis Riddington. "Redreaming the rural landscape." Futures 39 (2007): 324-339. DOI: 10.1016/j.futures.2006.04.002

Altman, Jon and Francis Markham. "Burgeoning Indigenous Land Ownership: Diverse Values and Strategic Potentialities." In Native Title from Mabo to Akiba: A Vehicle for Change and Empowerment? Eds. Sean Brennan, Megan Davis, Brendan Edgeworth and Leon Terrill. Annandale NSW: The Federation Press, 2015. 126-142.

Altman, Jon and Michelle Cochrane. "Indigenous Interests in Water: A Comment on the 'Water Property Rights-Report to COAG from the Water CEOs Group' Discussion Paper." Centre for Aboriginal Economic Policy Research (CAEPR), submission to the Council of Australian Governments, Australian National University, Canberra, 21 Feb. 2003.

Bell, Diane. Ngarrindjeri Wurruwarrin: A world that is, was, and will be. North Melbourne, Vic.: Spinifex, 1998.

Berndt. Ronald, Catherine Berndt, and John Stanton. A World That Was: The Yaraldi of the Murray River and The Lakes, South Australia. Carlton, Victoria: Melbourne UP, 1993.

Bhabha, Homi K. The Location of Culture. London: Routledge, 1994.

Biln, John. "(De)forming self and other: towards an ethics of difference”. In Postcolonial space(s). Eds. Gülsüm Baydar Nalbantoglu and Chong Thai Wong. New York: Princeton Architectural Press, 1997. 25-37.

Binney, Judith. Redemption Songs: a life of Te Kooti Arikirangi Te Turuki. Auckland N.Z.: Auckland UP with Bridget Williams Books, 1995.

Birckhead, Jim, Romy Greiner, Steve Hemming, Daryle Rigney, Matt Rigney, George Trevorrow and Tom Trevorrow. "Economic and Cultural Values of Water to the Ngarirndjeri People of the Lower Lakes, Coorong and Murray Mouth." Report to the Commonwealth Scientific and Industrial Research Organisation (CSIRO). Townsville, QLD: River Consulting, 2011.

Brearley, Laura, Kimba Thompson and Jacob Tolo, eds. Gulpa ngawal: Indigenous deep listening. Melbourne: RMIT University, 2010.

Brown, Greg, Christopher M. Raymond, and Jonathan Corcoran. "Mapping and Measuring Place Attachment.” Applied Geography 57 (2015): 42-53. DOI: 10.1016/j.apgeog.2014.12.011

Byrne, Denis. "The Ethos of Return: Erasure and Reinstatement of Aboriginal Visibility in the Australian Historical Landscape." Historical Archaeology 37.1, Recent Work in Historical Archaeology in Australia and New Zealand (2003): 73-86. https://www.jstor.org/stable/25617044

Calderon, Dolores. "Uncovering Settler Grammars in Curriculum." Educational Studies: A Journal of the American Educational Studies Association 50.4 (2014): 313-338. DOI:

$10.1080 / 00131946.2014 .926904$

Carter, Paul. The Road to Botany Bay: an Essay in Spatial History. London, Boston: Faber and Faber, 1987. 
Carter, Paul. The Lie of the Land. London; Boston: Faber and Faber, 1996.

Carter, Paul. Material Thinking: The Theory and Practice of Creative Research. Carlton, Victoria: Melbourne University Publishing, 2004.

Chance, Ian. Kaltja Now: Indigenous Arts Australia. Kent Town, S. Aust.: Wakefield Press, 2001.

Cleland, John Burton. “The Natives of South Australia." Proceedings of the Royal Geographical Society of Australasia, South Australian Branch 36 (1936): 16-29.

Clifford, James. Returns: Becoming Indigenous in the Twenty First Century. Cambridge, MA: Harvard UP, 2013.

Corowa Miriam. "Murray, Life + Death.” Message Stick. ABC TV, 2006.

Cullen, Peter. Water Challenges for South Australia in the Twenty First Century. Adelaide: Thinkers in Residence Program, Dept. of the Premier and Cabinet, 2004.

Cullen, Peter. Science and Politics: Speaking truth to power. Address to the North American Benthological Society Annual Conference. Anchorage, Alaska, USA: June 2006.

Demeritt, David. "Ecology, Objectivity and Critique in Writings on Nature and Human Societies." Journal of Historical Geography 20.1 (1994): 22-37. DOI: 10.1006/jhge.1994.1003

Deleuze, Gilles and Félix Guattari. Mille Plateaux. Paris: Éditions de Minuit, 1980.

Dodson, Michael. "The End in the Beginning: Re(de)finding Aboriginality." Australian Aboriginal Studies 1 (1994): 2-13.

Dunbar-Hall, Peter. Style and Meaning: Signification in Contemporary Aboriginal Popular Music, 1963-1993. Unpublished PhD Thesis, School of Music Education, University of New South Wales, 1994.

Dunlap, Thomas R. Nature and the English Diaspora: Environment and History in the United States, Canada, Australia and New Zealand. Cambridge, UK: Cambridge UP, 1999.

Farley Consulting Group. Indigenous Response to the Living Murray Initiative Report. Murray Darling Basin Commission, Canberra 2003.

Foster, Robert. An Imaginary Dominion. The Representation and Treatment of Aborigines in South Australia, 1834-1911. Unpublished PhD Thesis, Department of History, University of Adelaide, 1993.

Freire, Paulo. Pedagogy of the Oppressed. Harmondsworth: Penguin, 1970

Gawne, Ben, Rhonda Butcher, Jennifer Hale, Richard Kingsford, Kate Brandis, Viyanna Leo, Leanne Wheaton and Sally Hladyz. A Review of River Ecosystem Condition in the Murray-Darling Basin. Final Report prepared for the Murray-Darling Basin Authority (MDBA) by The MurrayDarling Freshwater Research Centre, 2011.

Gelder, Ken. "Thirty Years On: Reading the Country and Indigenous Homeliness." Australian Humanities Review 58 (2015): 17-25. http://australianhumanitiesreview.org/2015/05/01/thirtyyears-on-reading-the-country-and-indigenous-homeliness/

Gibson, Ross. Seven Versions of an Australian Badland. Saint Lucia, Qld: U. of Queensland P., 2002. Glissant, Édouard. L'Intention Poétique. Paris: Éditions du Seuil, Collection “Pierres Vives”, 1969. Glissant, Édouard. La Case du Commandeur. Paris: Éditions du Seuil, 1981a.

Glissant, Édouard. Le Discours Antillais. Paris: Éditions du Seuil, 1981b. 
Glissant, Édouard. “Baroque as a World Philosophy.” UNESCO Courier 21.1 (1987). 18-19.

Glissant, Édouard. Poétique de la Relation: Poétique III. Paris: Éditions Gallimard, 1990.

Glissant, Édouard. Introduction à une Poétique du Divers. Paris: Éditions Gallimard, 1995.

Glissant, Édouard. Poetics of Relation, trans. Betsy Wing. Ann Arbor: The University of Michigan

Press, 1997a.

Glissant, Édouard. Traité du Tout-Monde : Poétique IV. Paris: Éditions Gallimard, 1997b.

Glissant, Édouard. Une nouvelle région du monde : Esthétique I. Paris: Éditions Gallimard, Collection Blanche, 2006.

Goodall, Heather. "Renewing Country: Aboriginal People and their lands in rangeland environments.” The Rangeland Journal 23.1 (2001): 160-90. DOI: 10.1071/RJ01016

Goodall, Heather. 'Riding the Tide: Indigenous knowledge, history and water in a changing Australia.' Environment and History 14.3 (2008): 355-84. DOI: 10.3197/096734008X333563

Gover, Kristy. Tribal Constitutionalism: States, Tribes and the Governance of Membership. New York: Oxford UP, 2010.

Green, Donna, Ursula King and Joe Morrison. "Disproportionate burdens: The multidimensional impacts of climate change on the health of Indigenous Australians." Medical Journal of Australia 190 (2009): 4-5. DOI: 10.5694/j.1326-5377.2009.tb02250.x

Grinde, Donald and Bruce Johansen. Ecocide of Native America: Environmental destruction of Indian lands and peoples. Santa Fe: Clear Light Publishers, 1995.

Hallward, Peter. Absolutely Postcolonial: Writing Between the Singular and the Specific. Manchester; New York: Manchester UP, 2001.

Haraway, Donna. Primate Vision: Gender, Race, and Nature in the World of Modern Science. New York, London: Routledge, 1989.

Haraway, Donna. "Situated Knowledges: The Science Question in Feminism and the Privilege of Partial Perspectives.” Feminist Studies 14.3 (Autumn 1988): 575-99. DOI: 10.2307/3178066

Hattam, Robert, Daryle Rigney and Steve Hemming. "Reconciliation? Culture, nature and the Murray River." In Fresh Water: New Perspectives on Water in Australia. Eds. Emily Potter, Alison Mackinnon, Stephen McKenzie and Jennifer McKay. Carlton, Victoria: Melbourne UP, 2007. 105-22.

Hemming, Steve and Daryle Rigney. "Unsettling sustainability: Ngarrindjeri political literacies, strategies of engagement and transformation." Continuum 22.6 (2008): 757-75. DOI: $10.1080 / 10304310802452438$

Hemming, Steve and Daryle Rigney. "Ngarrindjeri Ruwe/Ruwar: wellbeing through caring for country." In Mental Health and Wellbeing: Educational Perspectives. Ed. Rosalyn H Shute.Adelaide: Shannon Research Press, 2011. 351-4.

Hemming, Steve and Daryle Rigney. "Indigenous Land Use and Occupancy Mapping as a Technology of Power." In Information Technology, Development, and Social Change. Eds. Fay Patel, Prahalad Sooknanan, Giselle Rampersad and Anuradha Mundkur. New York: Routledge, 2012. 128-38.

Hemming, Steve and Daryle Rigney. Indigenous Engagement in Environmental Water Planning, research and management innovation in South Australia's Murray-Darling Basin Region. Adelaide, South Australia: Flinders University: Goyder Institute for Water Research, 2014. 
Hemming, Steve, Daryle Rigney and Shaun Berg. "Researching on Ngarrindjeri Ruwe/Ruwar: Methodologies for positive transformation.” Australian Aboriginal Studies 2 (2010): 92-106.

Hemming, Steven and Tom Trevorrow. "Kungun Ngarrindjeri Yunnan: archaeology, colonialism and re-claiming the future." In Indigenous archaeologies: decolonising theory and practice. Eds. Claire Smith and H. Martin Wobst. London; New York: Routledge, 2005. 243-261.

Hemming, Steven, Daryle Rigney and Meryl Pearce. "Justice, culture and economy for the Ngarrindjeri Nation." In Fresh Water: New Perspectives on Water in Australia. Eds. Emily Potter, Alison Mackinnon, Stephen McKenzie and Jennifer McKay. Carlton, Victoria: Melbourne UP, 2007. 217-233.

Hercus, Luise, Flavia Hodges and Jane Simpson eds. The Land is a Map: placenames of Indigenous origin in Australia. Canberra: Pandanus Books, 2002.

Howitt, Richard and Sandra Suchet-Pearson. "Rethinking the building blocks: ontological pluralism and the idea of “management'”.' Geografiska Annaler B 88.3 (2006): 323-35. DOI: 10.1111/ j.1468-0459.2006.00225.x

Ingold, Tim. The Perception of the Environment: Essays on Livelihood, Dwelling and Skill. London and New York: Routledge, 2000.

Jackson, Sue, Brad Moggridge and Cathy Robinson. "Effects of changes in water availability on Indigenous people of the Murray-Darling Basin: a Scoping study." CSIRO Water for a Healthy Country: Report to the Murray Darling Basin Authority, 2010.

Jones, Patrick. Walking for food: Regaining permapoesis. Unpublished PhD Thesis, School of Humanities and Communication Arts, University of Western Sydney, 2013.

Johnson, Miranda. “Writing Indigenous Histories Now." Australian Historical Studies 45.3 (2014): 317-330. DOI: 10.1080/1031461X.2014.946525

Kämpf, Jochen and Diane Bell. “The Murray Coorong Estuary: Meeting of the Waters?” In Estuaries of Australia in 2050 and Beyond, Estuaries of the World. Ed. Eric Wolanski. Dordrecht: Springer, 2014.

Kartinyeri, Doreen and Sue Anderson. My Ngarrindjeri Calling. Canberra: Aboriginal Studies Press, 2008.

Koch, Harold and Luise Hercus, eds. Aboriginal Placenames: naming and re-naming the Australian landscape. Canberra: ANU E Press, 2009.

Kungun Ngarrindjeri Yunnan (Listen to the Ngarrindjeri Speaking): Ngarrindjeri Nation Yarluwar-Ruwe Plan, Caring for Ngarrindjeri Sea Country and Culture. Ngarrindjeri Tendi, Ngarrindjeri Heritage Committee, Ngarrindjeri Native Title Management Committee, 2006. https://www.environment.gov.au/indigenous/publications/pubs/ngarrindjeri-scp-2006-1.pdf

Kullberg, Christina. "Crossroads Poetics: Glissant and Ethnography.” Callaloo 36.4 (Autumn 2013): 968-82. DOI: 10.1353/cal.2013.0193

Latour, Bruno. Nous n'avons jamais été modernes: Essai d'anthropologie symétrique. Paris: La Découverte, 1991.

Lauer, Matthew and Shankar Aswani. "Indigenous Ecological Knowledge as situated practices: understanding Fishers' knowledge in the Western Solomon Islands." American Anthropologist 111.3 (2009): 317-29. DOI: 10.1111/j.1548-1433.2009.01135.x

Letters Patent of 1836. Letter Patent establishing the Province of South Australia. 19 Feb. 1836. http://www.foundingdocs.gov.au/resources/transcripts/sa2_doc_1836.pdf 
Livingstone, David. Putting Science in its Place: Geographies of Scientific Knowledge. Chicago: U. of Chicago P., 2003.

Mabey, Richard. Nature Cure. London: Vintage, 2015 [2005].

Mackinlay, Elizabeth. “'Memories of Landscape': The role of performance in naming, knowing, and claiming Yanyuwa country.' Journal of Australian Studies 29.86 (2005): 83-90. DOI:

$10.1080 / 14443050509388034$

Massey, Doreen. "Landscape as a Provocation: Reflections on Moving Mountains." Journal of Material Culture 11.33 (2006): 33-48. DOI: 10.1177/1359183506062991

Matthew, Freya. The Ecological Self. London: Routledge, 1994.

Mooney, Carla and Poh-Ling Tan. "South Australia's River Murray: Social and cultural values in water planning." Journal of Hydrology 474 (2012): 29-37. DOI: 10.1016/j.jhydrol.2012.04.010

Moreton-Robinson, Aileen. "The possessive logic of patriarchal white sovereignty: The High Court and the Yorta Yorta decision." In Taking Up the Challenge: Critical whiteness studies in a postcolonising nation. Ed. DW Riggs. Belair, SA: Crawford House, 2007. 109-124.

Muecke, Stephen, Kim Benterrak and Paddy Roe. Reading the Country: Introduction to Nomadology. South Fremantle, WA: Fremantle Arts Centre Press, 1996 [1984].

Muir, Cameron, Deborah Bird Rose and Phillip Sullivan. "From the Other Side of the Knowledge Frontier: Indigenous Knowledge, Social-Ecological Relationships and New Perspectives." The Rangeland Journal 32 (2010): 259-65. DOI: 10.1071/RJ10014

Ngarrindjeri lakun: Ngarrindjeri weaving. Meningie, South Australia: Ngarrindjeri Lands and Progress Association, 2013.

Norris, Richard, Ian Prosser, Bill Young, Peter Liston, Nicholas Bauer, Nerida Davies, Fiona Dyer, Simon Linke, and Martin Thoms. The assessment of river condition (ARC): an audit of the ecological condition of Australian rivers (Technical report from the CRC for Freshwater Ecology and CSIRO Land and Water to the National Land and Water Resources Audit). Canberra: CSIRO, 2001.

Oakley, Seanna Sumalee. Common Places: The Poetics of African Atlantic Postromantics. Amsterdam, New York: Rodopi, 2011.

Plumwood, Val. "Shadow Places and the Politics of Dwelling." Australian Humanities Review 44 (March 2008). http://www.australianhumanitiesreview.org/archive/Issue-March-2008/ plumwood.html

Povinelli, Elizabeth. The Cunning of Recognition: Indigenous Alterities and the Making of Australian Multiculturalism. Durham: Duke UP, 2002.

Potter, Emily. "Ecological Crisis and Australian Literary Representation." Australian Humanities Review 37, Eco-humanities Corner (December 2005): 1-8. http://australianhumanitiesreview.org/ 2005/12/01/ecological-crisis-and-australian-literary-representation/

Potter, Emily. "Reimagining place: The possibilities of Paul Carter's Nearamnew.” In Fresh Water: New Perspectives on Water in Australia. Eds. Emily Potter, Alison Mackinnon, Stephen McKenzie and Jennifer McKay. Carlton, Victoria: Melbourne UP, 2007. 246-258.

Power, Tom. “A Program of Recording Aboriginal Sites on the Murray River." Site Rec. Newsletter 1.3 (1977): 18-9.

Pretty, Jules, Bill Adams, Fikret Berkes, Simone Ferreira de Athayde, Nigel Dudley, Eugene Hunn, Luisa Maffi, Kay Milton, David Rapport, Paul Robbins, Eleanor Sterling, Sue Stolton, Anna Tsing, Erin Vintinner and Sarah Pilgrim. "The Intersections of Biological Diversity and Cultural 
Diversity: Towards Integration." Conservation and Society 7.2 (2009): 100-12. DOI:

10.4103/0972-4923.58642

Pretty, Jules. "Social Capital and the Collective Management of Resources." Science 302.5652

(2003): 1912-4. DOI: 10.1126/science.1090847

Pratt, Mary Louise. Imperial Eyes: Travel Writing and Transculturation. London, New York:

Routledge, 1992.

Pring, Adele. Women of the Centre. Apollo Bay, Victoria: Pascoe, 1990.

"Proclamation of Ngarrindjeri Dominium." Hand-delivered to the Governor of South Australia for presentation to the State Government, 17 Dec. 2003.

Rankine, Leila. "What the Coorong Means to Me." Aboriginal Human Relations Newsletter 13.30 (1974): 8-9.

Revell, Grant. Further studies in evaluating the landscape attractiveness of the Fleurieu Peninsula: stage two: landscape tracts--Myponga; Mount Cone; Mount Compass; Carrickalinga, Bungala, Yankalilla; Currency Creek, Goolwa; Quartz Knob; Congeratinga, Parananacooka, Yattagolinga; and Deep Creek. Adelaide, S. Aust.: National Trust of South Australia, 1982.

Riley, Kate. “Welcoming Back the River.” Australian Geographic 100 (Oct-Dec 2010): 37-8.

Roberts, Adam. “Good Poetry Is Like Good Food: How to Find It ... and Savor It." The Atlantic. 10 Nov. 2010. http://www.theatlantic.com/entertainment/archive/2010/11/good-poetry-is-likegood-food-how-to-find-it-and-savor-it/66308/

Robin, Libby. How a Continent Created a Nation. Sydney: U. of New South Wales P., 2007.

Robin, Libby, Robert Heinsohn and Leo Joseph, eds. Boom and Bust: Bird Stories for a Dry Country. Canberra: CSIRO Publishing, 2009.

Rose, Deborah Bird. Reports from a Wild Country: ethics for decolonisation. Sydney, NSW: University of New South Wales, 2004.

Rose, Deborah Bird. "Fresh Water Rights and Biophilia: Indigenous Perspectives." Dialogue 23.3 (2004): 35-43.

Rose, Deborah Bird. "Justice and Longing." In Fresh Water: New Perspectives on Water in Australia. Eds. Emily Potter, Alison Mackinnon, Stephen McKenzie and Jennifer McKay. Carlton, Victoria: Melbourne UP, 2007. 8-20.

Ryan, Siobhain. "Murray Inflows Slow to a Trickle." The Australian, 8 April 2009: 8.

Satchell, Kim. “Auto-choreography: Animating Sentient Archives." Cultural Studies Review 16.1 (March 2010): 104-118.

Scott, James C. Seeing Like a State: How Certain Schemes to Improve the Human Condition Have Failed. New Haven, Connecticut: Yale UP, 1998.

Sinclair, Paul. The Murray: A River and Its People. Melbourne: Melbourne UP, 2001.

Stein, Gertrude. Gertrude Stein: Selections. Joan Retallack, ed. Berkeley: U. of California P., 2008.

Spivak, Gayatri Chakravorty. In Other Worlds: Essays in Cultural Politics. New York: Methuen, 1987.

Taplin, George. Folklore, Manners, Customs, and Languages of the South Australian Aborigines: gathered from inquiries made by authority of South Australian Government. Adelaide: Govt. Press, 1879. 
Taplin, George. "From the banks of the Murray River, where it enters Lake Alexandrina, to the embouchure of that river and Lacepede Bay." In The Australian Race. Ed. Edward M. Curr.

Melbourne: John Ferres, Government Printer, 1886. 242-73.

Tindale, Norman. Aboriginal Tribes of South Australia: Their terrain, environmental controls, distributions, limits and proper names. Canberra: Australian National UP, 1974.

Tipa, Gail and Kyle Nelson. "Identifying Cultural Flow Preferences: Kakaunui River Case Study." Journal of Water Resources, Planning and Management 138.6 (2012): 660-70. DOI: 10.1061/(ASCE)WR. 1943-5452.0000211

Tjukonia, Vesper. "The Language of the Land." Canadian Women Studies/Les Cahiers de la Femme 23.1 (2003): 69-76.

Tuhiwai-Smith, Linda. Decolonising Methodologies: Research and Indigenous Peoples. London: Zed Books, 1999.

Tumarkin, Maria M. Traumascapes: the power and fate of places transformed by tragedy. Carlton, Vic.: Melbourne University Publishing, 2005.

Walker Brian and David Salt. Resilience Thinking: Sustaining Ecosystems and People in a Changing World. Washington: Island Press, 2006.

"Water flows: Indigenous views." Indigenous Newslines: a magazine on Aboriginal and Torres Strait Islander issues (Sept.-Nov. 2009): 8-13.

Watson, Irene. "Statement on behalf of the Tangankeld and Meingtangk peoples." The Australian Contribution: A survey of the positions put to the working group by representatives of the Australian government, the Aboriginal and Torres Strait Islander Commission, and the Australian non-government organisations. United Nations, 1992 Working Group on Indigenous Populations (Geneva, Switzerland). Canberra: Office of Public Affairs, ATSIC, 1992: 67-8.

Weir, Jessica K. Murray River Country: An ecological dialogue with traditional owners. Canberra: Aboriginal Studies Press, 2009.

Whyte, Kyle. "What do Indigenous Knowledges do for Indigenous Peoples?" In Keepers of the Green World: Traditional Ecological Knowledge and Sustainability. Eds. Melissa K. Nelson and Dan Shilling. Cambridge: Cambridge UP, forthcoming.

Wolfe, Patrick. "Settler colonialism and the elimination of the native." Journal of Genocide Research 8.4 (Dec 2006): 387-409. DOI: 10.1080/14623520601056240

Zamora, Lois Parkinson and Monika Kaup, eds. Baroque New Worlds: Representation, Transculturation, Counterconquest. Durham: Duke UP, 2010.

Zhu, Xuan, Sharron Pfueller, Paul Whitelaw and Caroline Winter. 'Spatial Differentiation of Landscape Values in the Murray River Region of Victoria, Australia.' Environmental Management 45 (2010): 896-911. DOI: 10.1007/s00267-010-9462-x

\section{ABSTRACTS}

In the context of severe environmental degradation, this article analyses governmental and Ngarrindjeri discourses surrounding the understanding and management of water in Lower Murray Country (South Australia). It shows that mutated colonial practices around water management in the Murray-Darling Basin have placed the Lower Murray region under unprecedented environmental threat. Future-oriented, paternalistic and linguistically 
intransigent poetics of elsewhere are used to justify the implementation of these monolingual practices, which gag alternative epistemologies. In response to this imperialistic water management (labelled as a second wave of dispossession), and strengthened by the growing recognition of Indigenous rights worldwide, Traditional Owners from the Basin have developed the concept of Cultural Flows to subtly subvert these silencing discourses and reclaim their right to a voice within governmental agencies involved in developing water management policies. This article argues that this reappropriated and re-rooted concept of Cultural Flows is merely the tip of a larger poetic shift in language, and can serve as a pivot around which to understand the mechanisms through which Aboriginal Nations, and in particular the Ngarrindjeri, weave their cultural practices, both figuratively and literally, within mainstream artistic and ecological discourses. Current manifestations of this shift, as expressed through visual arts (Riverland: Yvonne Koolmatrie, Art Gallery of South Australia), music (travelling performance project Ringbalin) and environmental politics (National Cultural Flows Research Project), are examined to demonstrate that this shift creates a new language which can be understood as a mode of highly localised Baroque speech (following Édouard Glissant's definition of the term).

Dans le contexte d'une grave dégradation environnementale, cet article analyse les discours gouvernementaux et Ngarrindjeri autour de l'eau et de sa gestion dans le Lower Murray Country (Australie Méridionale). Cet article montre qu'une gestion de l'eau aux relents coloniaux dans le bassin Murray-Darling expose la région Lower Murray à une menace écologique sans précédent. Une poétique de l'ailleurs, tournée vers le futur, paternaliste et intransigeante dans sa langue, est mise en œuvre pour tenter de justifier ces pratiques monolingues qui bâillonnent toute épistémologie alternative. En réponse à cette gestion impérialiste (décrite comme une deuxième vague de dépossession), et soutenus par la reconnaissance grandissante dans le monde du droit des populations indigènes, les propriétaires traditionnels du bassin ont développé le concept de Flux Culturels pour détourner ces discours étouffants et réaffirmer leur droit d'être entendus au sein des agences gouvernementales chargées de la gestion de l'eau. Cet article émet l'hypothèse que le concept ainsi réapproprié de Flux Culturels ne représente qu'un infime aspect d'un glissement poétique du langage et qu'il peut servir de pivot pour comprendre comment les Nations Aborigènes, et en particulier les Ngarrindjeri, (mé)tissent leurs pratiques culturelles, au sens tant littéral que figuré, dans les discours écologiques et artistiques dominants. Des manifestations contemporaines de ce glissement qui se dévoilent dans les arts plastiques (Riverland: Yvonne Koolmatrie, Art Gallery of South Australia), la musique (le projet-voyage Ringbalin) et la politique environnementale (National Cultural Flows Research Project) seront examinées pour démontrer que ce glissement crée un nouveau langage qui peut s'interpréter comme un discours baroque localisé (d'après la définition qu'en fait Édouard Glissant).

\section{INDEX}

Mots-clés: Lower Murray Country, Ringbalin, flux culturels, tissage, Ngarrindjeri, baroque, écopoétique, Australie, aborigène

Keywords: Lower Murray Country, Ringbalin, cultural flows, weaving, Ngarrindjeri, baroque, ecopoetics, Australia, Aboriginal 


\section{AUTHOR}

\section{CAMILLE ROULIĖRE}

Camille Roulière is a cotutelle $\mathrm{PhD}$ candidate at the J. M. Coetzee Centre for Creative Practice (University of Adelaide, Australia) and ERIBIA (University of Caen Normandie, France). Her research centres on spatial poetics and she investigates the links between place and art, and primarily music, in Lower Murray Country (South Australia). Her research specifically aims to trace, map and interpret cultural perceptions of these landscapes, and their evolution. Her academic interests range widely from digital and environmental humanities to Indigenous studies and ethnomusicology. Contact: camille.rouliere [at] adelaide.edu.au 